\title{
PREVENTION OF IMMUNE-MEDIATED CORNEAL GRAFT DESTRUCTION WITH THE ANTI-LYMPHOCYTE MONOCLONAL ANTIBODY, CAMPATH-1H
}

\author{
DOUGLAS K. NEWMAN ${ }^{1}$, JOHN D. ISAACS ${ }^{2}$, PETER G. WATSON ${ }^{1}$, PAUL A. R. MEYER ${ }^{1}$, \\ GEOFFREY HALE ${ }^{2}$ and HERMAN WALDMANN ${ }^{2}$ \\ Cambridge
}

\begin{abstract}
SUMMARY
We report a patient with peripheral rheumatoid corneal melting who developed a corneal perforation in one eye requiring tectonic keratoplasty. Nine consecutive corneal grafts were rapidly destroyed despite systemic immunosuppression with corticosteroid, cyclophosphamide, azathioprine and cyclosporin $A$. A rejection episode was observed in one graft before it melted and allograft rejection may have contributed to the destruction of other grafts. Corneal graft survival was ultimately achieved by systemic immunosuppression with the anti-lymphocyte monoclonal antibody, CAMPATH-1H. A single episode of rejection developed in the early post-operative period which was easily reversed by topical corticosteroid. Corneal melting has not recurred and the graft has now remained intact and clear for 24 months. Anti-lymphocyte monoclonal antibodies may therefore provide effective immunosuppression in the treatment of refractory ocular disorders.
\end{abstract}

Tectonic keratoplasty may be required in the treatment of rheumatoid corneal melting if the anatomical integrity of the eye is threatened. However, these grafts have a high failure rate due mainly to recurrent melting. ${ }^{1}$ Graft survival is enhanced by systemic immunosuppression to con-

From: ${ }^{1}$ Department of Ophthalmology, Addenbrooke's Hospital, Cambridge, UK; ${ }^{2}$ Department of Pathology (Immunology Division), University of Cambridge, Cambridge, UK.

Correspondence to: Mr D. K. Newman, MA, FRCOphth, Department of Ophthalmology, Clinic 3 (Box 41), Addenbrooke's Hospital, Hills Road, Cambridge CB2 2QQ, UK. trol the underlying rheumatoid disease. ${ }^{2}$ Effective immunosuppressive agents include corticosteroids, cyclophosphamide and azathioprine..$^{3-5}$ Pulsed intravenous immunosuppressive therapy may control disease unresponsive to oral therapy. ${ }^{6}$ Systemic immunosuppression also reduces the risk of irreversible graft rejection. Corticosteroids, cyclosporin A and azathioprine have been employed in high-risk keratoplasty as prophylaxis against rejection. ${ }^{7,8}$ HLA matching now appears to confer no additional benefit. ${ }^{9}$ Nevertheless, despite current immunosuppressive regimens, these grafts may still be subject to recurrent melting or rejection.

Anti-T-cell monoclonal antibodies (mAbs) provide highly specific and effective immunosuppression. Experimental studies have suggested their potential value in the treatment of immunemediated ocular disorders. Corneal graft survival is prolonged by peri-operative systemic mAb therapy ${ }^{10-13}$ while acute rejection episodes can be reversed by intracameral mAb administration. ${ }^{14}$ Systemic mAb therapy can also suppress autoimmune scleritis ${ }^{15}$ and uveitis. ${ }^{16}$ There are only two reports of anti-T-cell $\mathrm{mAbs}$ being used to treat ocular disorders in man, to reverse acute corneal graft rejection by intracameral administration. ${ }^{17,18}$

CAMPATH-1H is a humanised $\mathrm{IgG}_{1}$ mAb that is specific for the CD52 antigen present on all lymphocytes and monocytes but absent from other cells. ${ }^{19}$ It was created by introducing the hypervariable regions of a rat anti-CD52 mAb into a human immunoglobulin gene. ${ }^{20}$ The resultant humanised $\mathrm{mAb}$ is less immunogenic than the rat 'parent' 


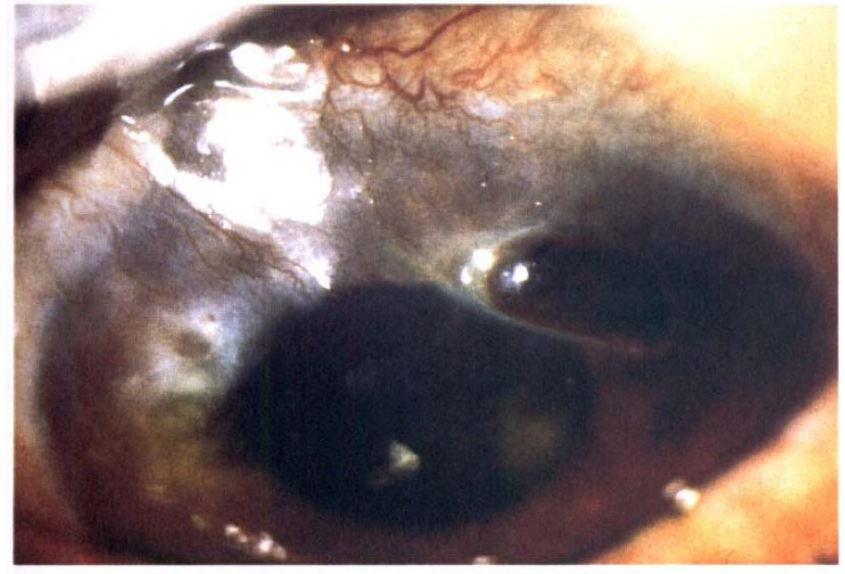

Fig. 1. Peripheral rheumatoid corneal melting in the left eye. An earlier corneal perforation at 10 o'clock was treated with a conjunctival flap. Progressive peripheral corneal melting has resulted in another perforation at 1 o'clock which is plugged by iris.

mAb. ${ }^{21}$ CAMPATH-1H is a highly effective immunosuppressive agent. Its administration is followed by a prolonged peripheral blood lymphopenia with a differential effect on lymphocyte subsets. ${ }^{21}$ T-cells are predominantly affected and remain depressed for many months, with $\mathrm{CD}^{+}$cells taking longer to recover than $\mathrm{CD}^{+}$cells. B-cells are also depleted, but rapidly recover. Natural killer cells and monocytes, however, are less susceptible to lysis by CAMPATH-1H and their peripheral blood counts fall only transiently.

CAMPATH-1H has been used to treat refractory cases of rheumatoid arthritis ${ }^{21,22}$ and systemic vasculitis. $^{23,24}$ Other anti-CD52 $\mathrm{mAbs}$ have proved effective in the prophylaxis ${ }^{25}$ and treatment ${ }^{26}$ of allograft rejection in renal transplantation. We report the use of CAMPATH-1H to treat a patient with immune-mediated corneal graft destruction that was resistant to immunosuppression with conventional agents.

\section{CASE REPORT}

A 70-year-old man with a 45-year history of seropositive rheumatoid arthritis was referred in July 1989 with progressive peripheral corneal melting in the left eye. His ocular problems had commenced in 1984 when he developed mild keratoconjunctivitis sicca. In October 1988, he developed peripheral

Table I. Tectonic corneal grafts performed in the left eye with concurrent systemic immunosuppression

\begin{tabular}{|c|c|c|c|c|}
\hline \multirow[b]{2}{*}{ Date } & \multirow[b]{2}{*}{ Tectonic corneal graft } & \multicolumn{2}{|c|}{ Systemic immunosuppression } & \multirow[b]{2}{*}{ Clinical course } \\
\hline & & $\begin{array}{l}\text { Peri-operative } \\
\text { intravenous therapy }\end{array}$ & $\begin{array}{l}\text { Maintenance oral } \\
\text { therapy }\end{array}$ & \\
\hline $26 / 7 / 89$ & 5-mm penetrating patch graft & MePred & None & Melt at $<1$ week \\
\hline $1 / 8 / 89$ & $5-\mathrm{mm}$ penetrating patch graft & MePred + CP $(\times 2)$ & Pred $+\mathrm{CP}$ & Melt at $<1$ week \\
\hline $8 / 8 / 89$ & $\begin{array}{l}\text { D-shaped lamellar keratoplasty } \\
\text { to superior half of cornea }\end{array}$ & MePred & Pred $+\mathrm{CP}$ & Melt at $<1$ week \\
\hline 2/9/89 & $\begin{array}{l}\text { 12-mm lamellar keratoplasty } \\
\text { (+ extracapsular cataract extraction) }\end{array}$ & MePred & Pred $+\mathrm{CP}$ & Melt + perforation at 4 weeks \\
\hline $2 / 11 / 89$ & 10-mm lamellar keratoplasty ${ }^{\mathrm{c}}$ & MePred & Pred $+\mathrm{CP}$ & $\begin{array}{l}\text { Melt }+ \text { descemetocoele formation at } \\
4 \text { weeks. Graft remained tectonically } \\
\text { sound for } 24 \text { months }\end{array}$ \\
\hline $2 / 6 / 92$ & 6-mm penetrating keratoplasty & MePred & Pred $+\mathrm{CP}$ & Melt + perforation at 4 weeks \\
\hline $11 / 7 / 92$ & 8 -mm penetrating keratoplasty & MePred & Pred + CsA + Aza & Melt + perforation at 4 weeks (Fig. 2$)$ \\
\hline $3 / 11 / 92$ & 11-mm penetrating keratoplasty & MePred $(\times 2)$ & Pred + CsA + Aza & $\begin{array}{l}\text { Allograft rejection at } 3 \text { weeks. } \\
\text { Treated with topical dexamethasone } \\
\text { and pulsed i.v. methylprednisolone. } \\
\text { Melt + perforation at } 6 \text { weeks }\end{array}$ \\
\hline $23 / 3 / 93$ & $\begin{array}{l}\text { 9.5-mm HLA-matched penetrating } \\
\text { keratoplasty ( }+ \text { subtotal iridectomy, } \\
\text { anterior vitrectomy) }\end{array}$ & None & Pred $^{\prime}+$ CsA + Aza & Melt + perforation at 4 weeks \\
\hline $23 / 4 / 93$ & 14-mm corneoscleral graft & САMРАТН-1H & Pred + CsA & $\begin{array}{l}\text { Allograft rejection at } 4 \text { weeks. } \\
\text { Resolved with topical } \\
\text { dexamethasone. Graft remains intact } \\
\text { and clear at } 24 \text { months (Fig. } 4 \text { ) }\end{array}$ \\
\hline
\end{tabular}

Each graft was performed by the same surgeon (P.G.W.). The first three grafts were eccentric, while the others were all central. Organcultured donor material ${ }^{27}$ was used for the first nine grafts. Fresh donor material was used for the final graft. Topical dexamethasone $0.1 \%$ and chloramphenicol $0.5 \%$ were administered after each graft.

${ }^{a}$ MePred, intraoperative pulse of i.v. methylprednisolone $(500 \mathrm{mg})$; MePred $+\mathrm{CP}$, intraoperative pulse of i.v. methylprednisolone $(1 \mathrm{~g})$ and cyclophosphamide $(500 \mathrm{mg}) ; \times 2$, pulse repeated after 48 hours.

${ }^{b}$ Pred, prednisolone ( $\left.15 \mathrm{mg} / \mathrm{day}\right) ; \mathrm{CP}$, cyclophosphamide ( $2 \mathrm{mg} / \mathrm{kg} /$ day); CsA, cyclosporin A (3 mg/kg/day); Aza, azathioprine (1.5 mg/kg/ day); Pred', prednisolone initially at high dose $(60 \mathrm{mg} /$ day), tapered (to $15 \mathrm{mg} / \mathrm{day})$ over 1 week.

${ }^{c} \mathrm{~A}$ full-thickness donor corneal button was sutured on the recipient lamellar bed.

${ }^{\mathrm{d}}$ The donor material had one mismatch at each of the HLA-A, B and DR loci. 


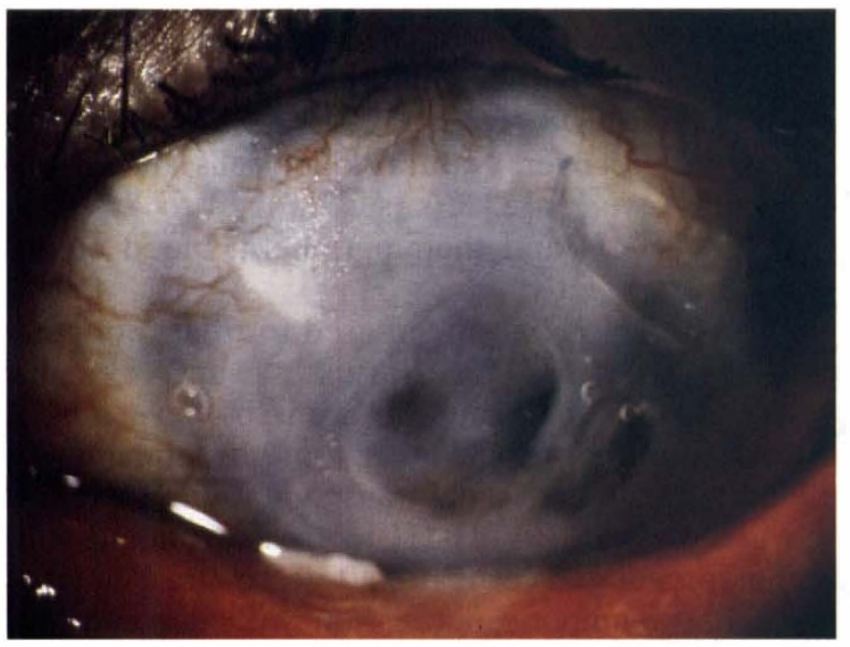

Fig. 2. Corneal grafts performed with conventional immunosuppressive regimens were rapidly destroyed. This 8-mm penetrating keratoplasty was performed with prednisolone, cyclosporin $A$ and azathioprine for systemic immunosuppression.

corneal melting at 10 o'clock in the right eye which rapidly progressed to perforation. This was successfully treated with a conjunctival flap. Four weeks later, another peripheral corneal melt developed at 1 o'clock in the right eye. This healed with a therapeutic contact lens and topical acetylcysteine $10 \%$. The right eye thereafter remained quiescent with an intact epithelium. He next presented, in June 1989 , with a peripheral corneal perforation at 10 o'clock in the left eye. While this settled with a conjunctival flap, the superior peripheral cornea continued to melt. Four weeks later, another perforation developed at 1 o'clock which was plugged by iris with a formed anterior chamber (Fig. 1). There was no associated scleral inflamma-

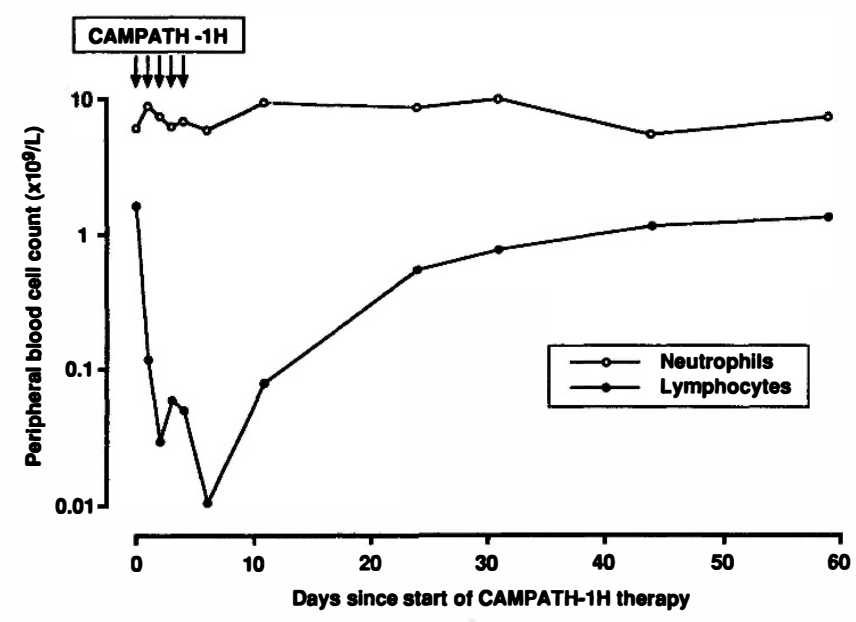

Fig. 3. Effect of CAMPATH-1H therapy on the peripheral blood cell count.

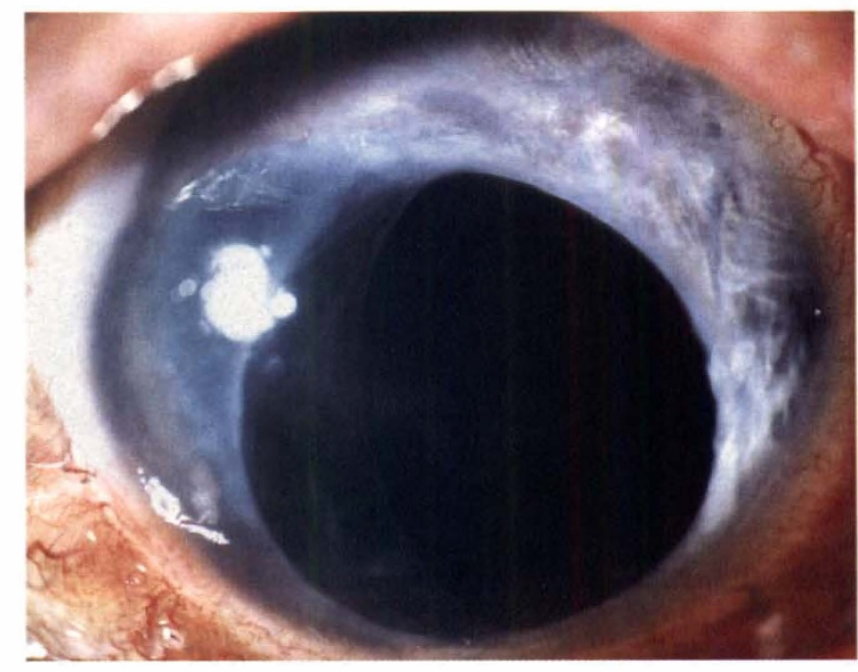

Fig. 4. Corneoscleral graft performed with CAMPATH$1 \mathrm{H}$, prednisolone and cyclosporin A for systemic immunosuppression. This graft has remained intact and clear.

tion. He was referred to Addenbrooke's Hospital for further treatment.

Tectonic keratoplasty was performed with concurrent systemic immunosuppression to control the rheumatoid corneal melting. His systemic rheumatoid disease was active at the time of referral (erythrocyte sedimentation rate $52 \mathrm{~mm} / \mathrm{h}$, C-reactive protein $62 \mathrm{mg} / \mathrm{l}$ and rheumatoid factor $332 \mathrm{IU} / \mathrm{ml}$ ). However, despite intensive immunosuppressive therapy, nine consecutive corneal grafts performed in the left eye were rapidly destroyed (Table I, Fig. 2). Treatment with corticosteroids, cyclophosphamide, azathioprine and cyclosporin $\mathrm{A}$ each failed to prevent recurrent melting of the graft. A rejection episode was observed in one graft, comprising diffuse graft thickening and keratic precipitates. Topical and systemic corticosteroids were given but the graft subsequently melted.

In April 1993, a 14-mm corneoscleral graft was performed using CAMPATH-1H for systemic immunosuppression. Informed consent was obtained from the patient. Fresh donor material was employed and the transplanted corneoscleral disc included limbus and perilimbal conjunctiva. CAMPATH-1H was administered as an intravenous infusion of $12 \mathrm{mg}$ antibody over 4 hours given daily for 5 consecutive days, with the first dose being given 12 hours prior to surgery (total dose $60 \mathrm{mg}$ antibody). ${ }^{21}$ This resulted in a profound peri-operative depletion of peripheral blood lymphocytes (Fig. 3). Oral prednisolone $(15 \mathrm{mg} /$ day) and cyclosporin A ( $7.5 \mathrm{mg} / \mathrm{kg}$ pre-operatively, followed by $3 \mathrm{mg} / \mathrm{kg} / \mathrm{day}$ ) were also given for maintenance immunosuppression.

The graft was initially clear and the donor epithelium remained intact. A rejection episode 
developed in the fourth post-operative week consisting of localised keratic precipitates and graft vascularisation at 7 o'clock. This was readily reversed by hourly topical dexamethasone $0.1 \%$. Recurrent corneal melting has not developed and there have been no further rejection episodes during 24 months follow-up (Fig. 4). The best corrected visual acuity is $6 / 12$. Ocular hypertension (probably steroid-related) has subsequently developed in both eyes, controlled by oral acetazolamide. Maintenance topical therapy comprises dexamethasone $0.1 \%$ (three times daily) and frequent artificial tears. Systemic immunosuppression is gradually being reduced and currently comprises oral prednisolone $(7.5 \mathrm{mg} /$ day $)$ and cyclosporin A $(2 \mathrm{mg} / \mathrm{kg} /$ day - whole blood level $75 \mu \mathrm{g} / \mathrm{l})$. The peripheral blood $\mathrm{CD} 4^{+}$cell count has remained depressed $\left(0.25 \times 10^{9} / 1\right)$, with a CD4/CD8 ratio of 0.29 . There have been no adverse effects from this immunosuppressive regimen.

\section{DISCUSSION}

We have reported a patient with peripheral rheumatoid corneal melting who required tectonic keratoplasty. Despite intensive systemic immunosuppression, nine consecutive corneal grafts performed in one eye were rapidly destroyed. In addition to recurrent rheumatoid melting, the later grafts were also at high risk of rejection since the recipient bed was heavily vascularised and actively inflamed. ${ }^{28}$ Rejection was observed in only one of these grafts, but may have occurred in others without being clinically evident because of concurrent melting. Graft survival was ultimately achieved by systemic immunosuppression with the anti-lymphocyte mAb, CAMPATH-1H. Corneal melting has not recurred in this graft during 24 months follow-up. A single episode of rejection did develop in the early post-operative period, but was easily reversed by topical corticosteroid.

Corneal melting results from the enzymatic degradation of stromal collagen and proteoglycans. $^{29}$ The exact pathogenesis in rheumatoid disease is uncertain, but it appears to be immunologically mediated involving both cell-mediated and humoral mechanisms. ${ }^{4,30-32}$ Corneal graft rejection is a T-cell-mediated process that destroys epithelial, stromal and endothelial cells. ${ }^{33,34}$ Irreversible rejection leads to graft oedema and opacification, but is not considered to cause loss of corneal tissue per se. The later grafts performed in our patient may have been subject to both rheumatoid melting and rejection. It is possible that the rapid graft destruction observed resulted from the combined effect of these two disorders. For example, stromal oedema due to graft rejection could exacerbate rheumatoid melting by exposing collagen fibrils to the action of collagenases. Similarly, rheumatoid melting could precipitate rejection by inducing aberrant expression of HLA class II antigens on cells in the graft. ${ }^{32}$

The immunosuppressive regimen employed for the final graft has achieved long-term graft survival. This may simply be due to continued systemic immunosuppression. CAMPATH-1H therapy itself results in prolonged peripheral blood lymphopenia. ${ }^{21}$ In addition, the patient continues to receive maintenance therapy with prednisolone and cyclosporin A. A more exciting possibility, however, is that CAMPATH-1H therapy has induced immunological tolerance to the final graft. In animal models of transplantation, anti-T-cell mAbs can induce graft tolerance even in sensitised recipients. ${ }^{35}$ Other experimental studies suggest that potent regulatory mechanisms exist which maintain the tolerant state once it has been established. ${ }^{36}$ In theory, it is therefore possible to control both allograft rejection and autoimmune disease in man by using anti-T-cell mAbs to reprogramme the immune system for tolerance. ${ }^{37}$ Whilst tolerance induction might account for the long-term survival of the final graft, this hypothesis can only be tested by withdrawal of maintenance immunosuppression with the obvious attendant risks.

We consider that CAMPATH-1H therapy was the principal factor which determined the survival of the final graft. While the immunosuppressive regimen included maintenance therapy with oral prednisolone and cyclosporin A, this background immunosuppression was no different from that employed unsuccessfully for previous grafts. The topical medication given after the final graft was also no different from that used previously. Transplantation of fresh limbal tissue may possibly have contributed to the success of the final graft by providing limbal stem cells, thereby promoting the establishment of a stable graft epithelium. If limbal allograft transplantation has been successful in this patient, the result may be significant in its own right since this procedure usually fails from rejection. ${ }^{38}$

CAMPATH-1H therapy is generally well tolerated and our patient suffered no adverse effects. A reaction may develop on the first day of treatment consisting of pyrexia, rigors, nausea and occasionally systemic hypotension. ${ }^{21}$ This first-dose reaction accompanies lymphocyte destruction and is probably mediated by released cytokines. The prolonged lymphopenia induced by CAMPATH-1H therapy can theoretically predispose to various infections. However, this does not appear to be a prominent problem in practice. ${ }^{21}$ Of course, conventional immunosuppressive agents such as corticosteroids, cytotoxic drugs and cyclosporin $\mathrm{A}$ are themselves not free of significant adverse effects.

In conclusion, $\mathrm{mAbs}$ show considerable promise as 
highly specific and effective immunosuppressive agents in the treatment of ocular disorders.

The authors are grateful to the staff of the Cambridge Therapeutic Antibody Centre for the production and supply of CAMPATH-1H. We are also grateful to $\mathrm{Mr}$ Christopher Liu, FRCOphth, for helpful comments and to Mrs Katherine Haslam for the photography. CAMPATH is a registered trademark of Burroughs Wellcome and The Wellcome Foundation.

Key words: Corneal transplantation, Graft rejection, Immunosuppression, Monoclonal antibodies, Rheumatoid arthritis, Ulcerative keratitis.

\section{REFERENCES}

1. Palay DA, Stulting RD, Waring GO, Wilson LA. Penetrating keratoplasty in patients with rheumatoid arthritis. Ophthalmology 1992;99:622-7.

2. Raizman MB, Sainz de la Maza M, Foster CS. Tectonic keratoplasty for peripheral ulcerative keratitis. Cornea 1991;10:312-6.

3. Jayson MIV, Easty DL. Ulceration of the cornea in rheumatoid arthritis. Ann Rheum Dis 1977;36:428-32.

4. Easty DL, Madden P, Jayson MIV, Carter C, Noble BA. Systemic immunosuppression in marginal keratolysis. Trans Ophthalmol Soc UK 1978;98:410-7.

5. Foster CS. Immunosuppressive therapy for external ocular inflammatory disease. Ophthalmology 1980; 87:140-50.

6. Meyer PAR, Watson PG, Franks W, Dubord P. 'Pulsed' immunosuppressive therapy in the treatment of immunologically induced corneal and scleral disease. Eye 1987;1:487-95.

7. Hill JC. Systemic cyclosporine in high-risk keratoplasty. Short- versus long-term therapy. Ophthalmology 1994;101:128-33.

8. MacKay IR, Bignell JL, Smith PH, Crawford BA. Prevention of corneal-graft failure with the immunosuppressive drug azathioprine. Lancet 1967;2:479-82.

9. The Collaborative Corneal Transplantation Studies Research Group. The Collaborative Corneal Transplantation Studies (CCTS). Effectiveness of histocompatibility matching in high-risk corneal transplantation. Arch Ophthalmol 1992;110:1392-403.

10. Duguid IGM, Koulmanda M, Mandel TE. Prolongation of heterotopic human corneal graft survival in mice treated with an anti-CD4 monoclonal antibody. Transplant Proc 1990;22(5):2107-8.

11. He YG, Ross J, Niederkorn JY. Promotion of murine orthotopic corneal allograft survival by systemic administration of anti-CD4 monoclonal antibody. Invest Ophthalmol Vis Sci 1991;32:2723-8.

12. Ayliffe W, Alam Y, Bell EB, McLeod D, Hutchinson IV. Prolongation of rat corneal graft survival by treatment with anti-CD4 monoclonal antibody. Br J Ophthalmol 1992;76:602-6.

13. Duguid IGM, Koulmanda M, Mandel TE. Effect of monoclonal antibody on corneal graft survival across major and minor histocompatibility mismatches. Transplant Proc 1993;25(1 Pt 1):844.

14. Williams KA, Standfield SD, Wing SJ, Barras CW, Mills RA, Comacchio RM, Coster DJ. Patterns of corneal graft rejection in the rabbit and reversal of rejection with monoclonal antibodies. Transplantation 1992;54:38-43.

15. Jabs DA, Prendergast RA. Autoimmune ocular disease in MRL/Mp-lpr/lpr mice is suppressed by
anti-CD4 antibody. Invest Ophthalmol Vis Sci 1991;32:2718-22.

16. Atalla L, Linker-Israeli M, Steinman L, Rao NA. Inhibition of autoimmune uveitis by anti-CD4 antibody. Invest Ophthalmol Vis Sci 1990;31:1264-70.

17. Ippoliti G, Fronterrè A. Use of locally injected anti-T monoclonal antibodies in the treatment of acute corneal graft rejection. Transplant Proc 1987; 19 (1 Pt 3):2579-80.

18. Ippoliti G, Fronterrè A. Usefulness of CD3 or CD6 anti-T monoclonal antibodies in the treatment of acute corneal graft rejection. Transplant Proc 1989; 21 (1 Pt 3):3133-4.

19. Hale G, Xia M-Q, Tighe HP, Dyer MJS, Waldmann H. The CAMPATH-1 antigen (CDw52). Tissue Antigens 1990;35:118-27.

20. Riechmann L, Clark M, Waldmann H, Winter G. Reshaping human antibodies for therapy. Nature 1988;332:323-7.

21. Isaacs JD, Watts RA, Hazleman BL, Hale G, Keogan MT, Cobbold SP, Waldmann H. Humanised monoclonal antibody therapy for rheumatoid arthritis. Lancet 1992;340:748-52.

22. Kyle V, Roddy J, Hale G, Hazleman BL, Waldmann H. Humanized monoclonal antibody treatment in rheumatoid arthritis. J Rheumatol 1991;18:1737-8.

23. Mathieson PW, Cobbold SP, Hale G, Clark MR, Oliveira DBG, Lockwood CM, Waldmann H. Monoclonal-antibody therapy in systemic vasculitis. N Engl J Med 1990;323:250-4.

24. Lockwood CM, Thiru S, Isaacs JD, Hale G, Waldmann $\mathrm{H}$. Long-term remission of intractable systemic vasculitis with monoclonal antibody therapy. Lancet 1993;341:1620-2.

25. Friend PJ, Hale G, Waldmann H, Gore S, Thiru S, Joysey $\mathrm{V}$, et al. Campath-1M - prophylactic use after kidney transplantation. A randomised controlled clinical trial. Transplantation 1989;48;248-53.

26. Friend PJ, Waldmann H, Hale G, Cobbold S, Rebello $\mathrm{P}$, Thiru S, et al. Reversal of allograft rejection using the monoclonal antibody, CAMPATH-1G. Transplant Proc 1991;23(4):2253-4.

27. Pels E, Schuchard Y. Organ-culture preservation of human corneas. Doc Ophthalmol 1983;56:147-53.

28. Williams KA, Roder D, Esterman A, Muehlberg SM, Coster DJ. Factors predictive of corneal graft survival. Report from the Australian Corneal Graft Registry. Ophthalmology 1992;99:403-14.

29. Kenyon KR. Decision-making in the therapy of external eye disease. Noninfected corneal ulcers. Ophthalmology 1982;89:44-51.

30. Eiferman RA, Carothers DJ, Yankeelov JA. Peripheral rheumatoid ulceration and evidence for conjunctival collagenase production. Am J Ophthalmol 1979;87:703-9.

31. Michels ML, Cobo LM, Caldwell DS, Rice JR, Haynes BF. Rheumatoid arthritis and sterile corneal ulceration. Analysis of tissue immune effector cells and ocular epithelial antigens using monoclonal antibodies. Arthritis Rheum 1984;27:606-14.

32. Kervick GN, Pflugfelder SC, Haimovici R, Brown H, Tozman E, Yee R. Paracentral rheumatoid corneal ulceration. Clinical features and cyclosporin therapy. Ophthalmology 1992;99:80-8.

33. Khodadoust AA, Silverstein AM. Transplantation and rejection of individual cell layers of the cornea. Invest Ophthalmol 1969;8:180-95.

34. Khodadoust AA, Silverstein AM. Induction of corneal 
graft rejection by passive cell transfer. Invest Ophthalmol 1976;15:89-95.

35. Cobbold SP, Martin G, Waldmann H. The induction of skin graft tolerance in major histocompatibility complex-mismatched or primed recipients: primed T cells can be tolerized in the periphery with anti-CD4 and anti-CD8 antibodies. Eur J Immunol 1990;20:2747-55. 36. Qin S, Cobbold SP, Pope H, Elliott J, Kioussis D,
Davies J, Waldmann H. 'Infectious' transplantation tolerance. Science 1993;259:974-7.

37. Cobbold SP, Qin S, Leong LYW, Martin G, Waldmann $\mathrm{H}$. Reprogramming the immune system for peripheral tolerance with CD4 and CD8 monoclonal antibodies. Immunol Rev 1992;129:165-201.

38. Thoft RA, Sugar J. Graft failure in keratoepithelioplasty. Cornea 1993;12:362-5. 